Acta Universitatis Wratislaviensis • No 4046

Literatura i Kultura Popularna XXVI, Wrocław 2020

https://doi.org/10.19195/0867-7441.26.11

\author{
Joanna Płoszaj \\ ORCID: 0000-0002-8302-0917 \\ Uniwersytet Wrocławski
}

\title{
Krew i brud. \\ Uwagi na temat estetyki oraz poetyki opisów śmierci w cyklu o wiedźminie Andrzeja Sapkowskiego
}

Słowa kluczowe: Andrzej Sapkowski, Wiedźmin, fantasy, literatura polska, literatura popularna, pornografia śmierci, literackie obrazy ciała, śmierć w literaturze

Keywords: Andrzej Sapkowski, fantasy, The Witcher series, Polish literature, popular literature, pornography of death, literary images of a human's body, death in literature

\section{Debiut Andrzeja Sapkowskiego i jego znaczenie dla rozwoju polskiej literatury fantasy}

Gdy w 1986 roku Andrzej Sapkowski opowiadaniem Wiedźmin debiutował na łamach miesięcznika „Fantastyka”, prawdopodobnie nikt, włącznie z redaktorami czasopisma, nie przypuszczał, że tekst ten okaże się przełomowy dla polskiej literatury fantastycznej: zapoczątkuje nie tylko jeden z najpopularniejszych polskich cykli literackich ${ }^{1}$, lecz także — w dalszej perspektywie — jedyny jak

${ }^{1}$ Cykl o wiedźminie składa się obecnie z dwóch tomów opowiadań: Ostatnie życzenie (1993) i Miecz przeznaczenia (1992) oraz powieści: Krew elfów (1994), Czas pogardy (1995), Chrzest ognia (1996), Wieża Jaskótki (1997), Pani Jeziora (1999), a także wydanego po 14 latach Sezonu burz (2013). Dla całościowego ujęcia dzieła Sapkowskiego proponuję określenie „cykl o wiedźminie”/,cykl wiedźmiński”, świadomie unikając popularnego „saga o wiedźminie”. Przede wszystkim dlatego, że to drugie odnosi się jedynie do publikowanego w latach dziewięćdziesiątych XX wieku powieściowego pięcioksięgu, a zatem jest określeniem węższym. Ponadto zostało ono arbitralnie narzucone przez wydawcę. Sam autor był temu niechętny, prawdopodobnie mając świadomość genologicznych uwikłań słowa ,saga”, które zostało tu błędnie zaproponowane. Zob. A.E. Gra- 
dotąd supersystem rozrywkowy utworzony wokół bohatera wykreowanego przez polskiego autora ${ }^{2}$. Utwór został nadesłany w ramach ogłoszonego przez redakcję miesięcznika Drugiego Konkursu Literackiego „Fantastyki”, a sam Sapkowski przyznawał, że miał nadzieję, iż sięgnięcie po mało wówczas jeszcze w Polsce znany — jak mu się zdawało - gatunek literatury popularnej ${ }^{3}$ wyróżni go na tle innych autorów ${ }^{4}$. Nikła obecność fantasy w oficjalnym obiegu wydawniczym nie oznaczała bynajmniej braku zainteresowania wśród odbiorców i początkujących twórców - wynikała raczej z niezrozumienia wspomnianego gatunku przez redaktorów preferujących inne odmiany literatury fantastycznej — w szczególności science fiction. Debiut Sapkowskiego prawdopodobnie najlepiej odzwierciedlał tę sytuację, łódzki autor zajął bowiem w konkursie trzecie miejsce ${ }^{5}$, co Maciej Parowski (jeden z członków jury) po latach komentował następująco: „lobby fantastyki problemowej było wówczas w »Fantastyce« silniejsze od rozrywkowego, a »Wiedźmin« za dobrze się czytał, by stanąc na szczycie podium"6.

Określenie „za dobrze się czytał” wydaje się tu zresztą kluczowe, ponieważ spośród wszystkich opublikowanych prac konkursowych to właśnie Wiedźmin zo-

bowski, Kilka opowiadań mi się udało [wywiad z A. Sapkowskim], https://sapkowskipl.wordpress. com/2017/03/13/kilka-opowiadan-mi-sie-udalo/ (dostęp: 9.08.2019).

2 Wnikliwą analizę procesu powstawania pierwszego polskiego supersystemu rozrywkowego przeprowadził Zbigniew Wałaszewski (zob. idem, Wiedźmin: pierwszy polski supersystem rozrywkowy, [w:] Obraz literatury w komunikacji społecznej po roku '89, red. A. Werner, T. Żukowski, Warszawa 2013). Warto podkreślić, że wraz ze światowym sukcesem gry Wiedźmin 3: Dziki Gon (prod. i wyd. CD Projekt RED, 2015) oraz wyprodukowanego przez platformę VOD Netflix opierającego się na motywach prozy Sapkowskiego serialu Wiedźmin (The Witcher, 2019-, Netflix, Polska-USA 2019) supersystem ten zyskał zasięg globalny.

3 Termin ,gatunek" będzie tu stosowany nie w rozumieniu poetyki normatywnej, lecz w znaczeniu, jakie w odniesieniu do literatury popularnej zostało zaproponowane na wzór literaturoznawstwa anglosaskiego przez Annę Gemrę, Tadeusza Żabskiego czy Jakuba Zdzisława Lichańskiego, czyli jako „struktury wyróżniane na podstawie kryteriów tematycznych, uporządkowania estetycznego, rozwiązań fabularnych, języka i stylu narracji” (A. Gemra, Literatura popularna. Literatura gatunków?, [w:] Retoryka i badania literackie. Rekonesans, red. J.Z. Lichański, Warszawa 1998, s. 72). Zob. także J.Z. Lichański, Literatura fantasy jako problem genologiczny (na przykładzie twórczości C.S. Lewisa i J.R.R. Tolkiena), [w:] Genologia i konteksty, red. C.P. Dutka, M. Mikołajczak, Zielona Góra 2000, s. 139-150; T. Żabski, Literatura popularna, [hasło w:] Stownik literatury popularnej, red. T. Żabski, Wrocław 2006, s. 212-217.

4 „Na konkurs »Fantastyki« napisałem nowelkę w gatunku fantasy — zachowałem się jak rasowy marketingowiec, myślałem, że oto znalazłem sposób na konkurencję. Mniemałem, że polska fantastyka to wciąż Lem i Zajdel [...]. Było to mniemanie naiwne, na ów konkurs wszyscy niemal napisali fantasy” (B. Chaciński, Jestem ful-tajm rajterem [wywiad z A. Sapkowskim], „Machina" 2000, nr 4, https://sapkowskipl.wordpress.com/2017/03/11/jestem-ful-tajm-rajterem/ (dostęp: 27.01.2020).

5 Ex aequo z Aleksandrem Bukowieckim i Markiem Dyszlewskim. Laureatem pierwszego miejsca został Marek S. Huberath, drugie zaś przypadło w udziale Janowi Maszczyszynowi. Zob. „Fantastyka” 1987, nr 9, s. 4.

6 M. Parowski, Odkrywanie AS-a, Gram.pl, https://www.gram.pl/artykul/2007/10/24/odkrywanie-as-a.shtml (dostęp: 8.08.2019). 
stał najbardziej doceniony przez odbiorców i w sondażu uznano go za najlepsze polskie opowiadanie roku ${ }^{7}$. W oczach czytelników — coraz wyraźniej zainteresowanych fantasy - debiutanckie opowiadanie Sapkowskiego wyróżniało się zarówno na tle nielicznych dostępnych wówczas w Polsce przekładów kanonicznych dzieł tego gatunku, jak i wczesnych tekstów rodzimych autorów ${ }^{8}$. Wynikało to z kilku przyczyn. Przede wszystkim ze względu na niewielką liczbę tłumaczeń literatury fantasy na język polski brakowało lokalnych tradycji gatunku, dostęp do tekstów oryginalnych był z kolei utrudniony ze względów politycznych. Pierwsze polskie utwory fantasy były zatem pisane wyraźnie na wzór tych anglojęzycznych, co widoczne jest zarówno w warstwie językowej, jak i kompozycyjnej. Ponadto stosunkowo najłatwiej dostępne były przekłady fantasy mitopoetyckiej, co rzutowało na postrzeganie gatunku przede wszystkim przez pryzmat jednego wzorca kompozycyjnego 9 . Debiut Sapkowskiego oferował natomiast nieznane

7 Zob. A. Hollanek, K. Szolgina, Sondaż III. Wyniki!, „Fantastyka” 1987, nr 12, s. 31-34. Warto zauważyć, że kolejne publikowane na łamach „Fantastyki” utwory Sapkowskiego, między innymi Droga, z której się nie wraca (1988) czy Ziarno prawdy (1989), również zajmowały w sondażu pierwszą pozycję w kategorii opowiadanie polskie (zob. K. Szolgina, Sondaż V-wyniki, „Fantastyka” 1989, nr 12, s. 54-56; Sondaż VI - opowiadania polskie, „Nowa Fantastyka” 1990, nr 9, s. 72). Z jednej strony potwierdza to zainteresowanie, jakim twórczość łódzkiego autora cieszyła się wśród czytelników, którzy już po publikacji Wiedźmina w listach do redakcji przesyłali sugestie, by Geralta uczynić bohaterem cyklu literackiego. Z drugiej — wskazuje, że przez kilka lat po debiucie Sapkowskiego nie pojawił się autor, który mógłby z nim konkurować pod względem popularności, co otworzyło mu drogę do dominacji na polu polskiej literatury fantasy. O skali oddziaływania debiutanckiego opowiadania Sapkowskiego świadczy także to, że Wiedźmin w obiegowej opinii — choć niesłusznie - bywa uważany za pierwszy polski tekst fantasy. Zob. A. Gemra, Fantasy po polsku. Kilka uwag nad twórczością Andrzeja Sapkowskiego, „Europa Orientalis” 2000, nr 1, s. 173.

8 Przed Sapkowskim jako autorzy fantasy debiutowali między innymi Jarosław Grzędowicz (Twierdza Trzech Studni, 1982), Feliks W. Kres (właśc. Witold Chmielecki; Mag, 1983) i Jacek Piekara (Wszystkie twarze Szatana, 1983; rok później opublikował również opowiadanie Smok, które uważa się za pierwszy polski tekst w konwencji miecza i czarów). Małgorzata Tkacz (Baśnie zbyt prawdziwe. Trzydzieści lat fantasy w Polsce, Gdańsk 2012) i Katarzyna Kaczor (Z „getta” do mainstreamu. Polskie pole literackie fantasy [1982-2012], Kraków 2017) — autorki monograficznych ujęć polskiej literatury fantasy oraz związanego z nią dyskursu - datę publikacji opowiadania Grzędowicza uznają za początek istnienia rodzimej fantasy.

9 Do lat osiemdziesiątych XX wieku polscy czytelnicy mogli zapoznać się jedynie z przekładami dzieł Johna Ronalda Reuela Tolkiena wydanymi jeszcze w latach sześćdziesiątych: Hobbitem, czyli tam i z powrotem (The Hobbit or There and Back Again, 1937; pol. 1960) oraz Władca Pierścieni (The Lord of the Rings, 1954-1955; pol. 1961-1963), których wznowienia ukazały się dopiero po 20 latach w związku z planowanym pierwszym polskim wydaniem Silmarillionu (1985). W 1983 roku nakładem Wydawnictwa Literackiego ukazał się zablokowany wcześniej przez cenzurę (ze względu na autora przekładu - Stanisława Barańczaka) Czarnoksiężnik z Archipelagu (The Wizard of the Eardsea , 1968) Ursuli K. Le Guin, w tym samym roku na łamach „Fantastyki” opublikowano również — w dwóch częściach — Świat czarownic (Witch World, 1963) Andre Norton (cyk1 „Świat Czarownic” ukazywał się nakładem Wydawnictwa „Amber” od 1990 roku). Natomiast w 1985 roku w tym samym miesięczniku opublikowano pierwsze oficjalne przekłady opowiadań o Conanie: Wie$\dot{z} a$ stonia (The Tower of the Elephant, 1933) oraz Spotkanie $w$ krypcie (The Thing in The Crypt, 1967), przy czym tylko pierwsze z nich jest autorstwa Roberta E. Howarda — inicjatora cyklu - 
dotąd polskiemu czytelnikowi podejście do konwencji — odwołując się do stosunkowo słabo znanej w Polsce tradycji przygodowej literatury fantasy (sword and sorcery), łódzki autor tworzył w sprzeczności ze znanym dłużej wzorcem tolkienowskim, który był już postrzegany jako coraz mniej atrakcyjny — głównie ze względu na to, iż kojarzono go ze schematami inicjacyjnej literatury młodzieżowej. Dodatkowo utwór prezentował wykrystalizowany styl autora, łączący w sobie: żywy, barwny język narracji oraz dynamiczną kompozycję tekstu, ironiczny humor dialogów, intertekstualne odniesienia do literackiego kanonu (w tym do nieznanego ówcześnie polskiemu czytelnikowi kanonu fantasy), zabawę konwencją, a także bardzo obrazowe opisy przemocy oraz śmierci. Katarzyna Kaczor zauważa, że Sapkowski wyznaczył w ten sposób pierwszy z archetekstów rodzimej literatury fantasy ${ }^{10}$, który można by uznać za prototyp polskiej fantasy przygodowej. Dzięki temu od debiutu Sapkowskiego fantasy w Polsce zaczęło rozwijać się w zawrotnym tempie, nie będąc — jak dotąd — anachronicznym względem anglosaskich realizacji gatunku ${ }^{11}$.

Kreacja świata przedstawionego, bezkompromisowość w ukazywaniu przemocy oraz naturalistyczne ujęcie śmierci bez wątpienia były jednymi z waż-

drugie zaś zostało napisane przez jego kontynuatorów: Lyona Sprague de Campa i Lina Cartera. Z kolei rok później Nasza Księgarnia wydała Niekończąca się historię (Die Unendliche Geschichte, 1979) Michaela Endego. W latach 1985-1989 nakładem Instytutu Wydawniczego „Pax” ukazały się także „Opowieści z Narnii” (,The Chronicles of Narnia”, 1950-1956) Clive’a Staplesa Lewisa. Przekłady dzieł ważnych autorów fantasy (między innymi wspomnianych wcześniej Le Guin, Norton i Howarda czy też nieobecnych jeszcze w oficjalnym obiegu Piersa Anthony'ego, Karla E. Wagnera i Rogera Zelaznego) ukazywały się za pośrednictwem fandomu w formie tak zwanych klubówek, ich zasięg był jednak ograniczony środowiskowo. Ponadto w tym wypadku nadrzędnym kryterium doboru publikowanych przekładów był dostęp do wydania oryginalnego. Zob. M. Roszczynialska, Sztuka fantasy Andrzeja Sapkowskiego. Problemy poetyki, Kraków 2009, s. 12; K. Kaczor, Między obiegami. Powstanie polskiego pola literackiego fantasy 1982-1990, [w:] Przyjemność (z) czytania. Pamięci Profesora Tadeusza Żabskiego, red. A. Gemra, Wrocław 2019; eadem, Z getta..., s. 38-39.

${ }^{10} \mathrm{~K}$. Kaczor, Bogactwo polskich światów fantasy. Od braku nadziei do eukatastophe, [w:] Anatomia wyobraźni, red. S.J. Konefał, Gdańsk 2014, s. 185-186. Badaczka znaczenie terminu „archetekst” przyjmuje za Ryszardem Nyczem jako „swego rodzaju prototyp, reprezentujący egzemplarz idealny (niekoniecznie realnie istniejący), który najlepiej spełnia gatunkowe normy [...] jako reprezentacja rzeczywistego egzemplarza wzorcowego" (idem, Tekstowy świat. Poststrukturalizm a wiedza o literaturze, Warszawa 1995, s. 42). Dyskusyjne pozostaje, czy drugi ze wskazanych przez Kaczor archetekstów, czyli militarna narracja Kresa — autora dziś już nieco zapomnianego, rzeczywiście odegrał tak istotną rolę w formowaniu się polskiej literatury fantasy.

11 Młodzi autorzy (jak choćby Rafał Ziemkiewicz, który w 1990 roku wydał zbiór Skarby Stolinów, czy Artur Szrejter, który akcję swoich opowiadań, takich jak wydane w 1991 roku Wieszczy i Król Pótnocy, a także opublikowane rok później Cztery Wesela, umiejscowił w realiach dawnej Słowiańszczyzny) zaczęli poszukiwać własnych ścieżek, tworząc między innymi nurt tak zwanej fantasy słowiańskiej, mocno zresztą przez Sapkowskiego skrytykowany w głośnym eseju Piróg, albo Nie ma złota w Szarych Górach („Nowa Fantastyka” 1993, nr 5, s. 65-72). Paradoksalnie w wywiadzie udzielonym kilka lat wcześniej Ziemkiewiczowi dla „Fantastyki” Sapkowski mówił: „nasze baśnie, nasza demonologia to naprawdę wspaniały materiał na fantasy” (R. Ziemkiewicz, Rozpędzam się [wywiad z A. Sapkowskim], „Fantastyka” 1988, nr 8, s. 52).

Literatura i Kultura Popularna 26, 2020

(C) for this edition by CNS 
niejszych czynników decydujących o popularności twórczości Sapkowskiego. Miały również istotny wpływ na charakter polskiej literatury fantasy. Brutalna rzeczywistość prezentowana przez łódzkiego autora wyróżniała się na tle utworów, z którymi mógł dotąd zapoznać się polski czytelnik — w porównaniu z dziełami Johna R.R. Tolkiena czy Ursuli K. Le Guin sprawiała wrażenie żywszej: „prawdziwszej”, „mniej baśniowej”. Dzięki temu twórczość Sapkowskiego była postrzegana jako fantasy skierowana przede wszystkim do dorosłego odbiorcy ${ }^{12}$. Przekonanie to wyraźnie wpłynęło na kształt rodzimych realizacji gatunku w kolejnych latach ${ }^{13}$, pisarze chętnie sięgali bowiem po brutalne opisy, próbując realizować zapoczątkowany przez autora Wiedźmina wzorzec, żadnemu z nich nie udało się jednak powtórzyć sukcesu na podobną skalę ${ }^{14}$. Warto zatem bliżej przyjrzeć się zaprezentowanym w cyklu o wiedźminie scenom śmierci i zastanowić się, które z elementów prezentowanych przez Sapkowskiego deskrypcji mogły najmocniej wpłynąć na ich wyjątkową sugestywność. Naturalistyczne obrazowanie biologicznych i fizjologicznych aspektów zgonu ${ }^{15}$ bez wątpienia wyróżniało cykl wiedźmiński na tle innych znanych polskiemu odbiorcy utworów fantasy. Wydaje się jednak, że wspomniana sugestywność opisów wynika nie tylko z ich brutalnej estetyki, ale jest również związana z poetyką kompozycji, na którą składają się: przygodowa dynamika opisu, wybór elementów eksponowanych w deskrypcji oraz sposób ich wyróżniania, a także zespół środków narracyjnych pozwalających na zniesienie emocjonalnego dystansu względem prezentowanych scen śmierci.

12 Zob. K. Kaczor, Bogactwo..., s. 185.

13 Można zauważyć, że między innymi w związku z tym w Polsce niemal nie rozwinęła się fantasy mitopoetycka. Wydana w 1988 roku powieść Anny Borkowskiej Gar'Ingawi, wyspa szczęśliwa została niemal niezauważona. Cykl o zbóju Twardokęsku Anny Brzezińskiej, realizujący wzorzec fantasy mitopoetyckiej z wyraźnymi odniesieniami do rodzimej historii, w pierwszym wydaniu (Zbójecki gościniec, 1999) był nieczytelny ze względu na zbyt daleko idące i zaburzające strukturę powieści ingerencje redakcyjne. Dodatkowym czynnikiem działającym na jego niekorzyść okazała się kampania marketingowa porównującą twórczość Brzezińskiej z cyklem o wiedźminie. Dopiero powstanie w 2002 roku Agencji Wydawniczej „Runa” pozwoliło na opublikowanie z nieco większym sukcesem kilku pozycji rodzimej fantasy mitopoetyckiej, w tym pełnego wydania cyklu o zbóju Twardokęsku — tym razem w kształcie zgodnym z intencjami autorki — i cyklu o Smoczogórach Wita Szostaka.

14 Śladem sprawdzonych u Sapkowskiego rozwiązań podążali między innymi Eugeniusz Dębski w cyklu o Hondelyku i Cadronie, Tomasz Bochiński w cyklu o Elizabediacie Moncku czy Konrad T. Lewandowski w „Sadze o Kotołaku”, jednak żaden ze wspomnianych cykli nie zyskał takiego uznania jak ten o wiedźminie.

15 Ze względu na wieloznaczność słowa „śmierć”, które można rozumieć zarówno jako moment śmierci biologicznej, przedstawienie zmarłego, moc, która zabija, a zatem śmierć upersonifikowaną, jak i czasoprzestrzeń zaświatów (zob. M. Guiomar, Zasady estetyki śmierci, [w:] Wymiary śmierci, red. S. Rosiek, przeł. M. Ochab, T. Swoboda, M.L. Kalinowski, Gdańsk 2010, s. 77-94), warto podkreślić, że przedstawiona w niniejszym tekście analiza będzie dotyczyła przede wszystkim opisów śmierci biologicznej, martwego ciała oraz poprzedzających śmierć aktów przemocy, ponieważ to one zostają w cyklu o wiedźminie najbardziej wyeksponowane. 


\section{Śmierć dynamiczna}

Cykl o wiedźminie - zwłaszcza w swoich początkach - jest mocno zakorzeniony $\mathrm{w}$ tradycji fantasy przygodowej ${ }^{16}$. Obrazowo zaprezentowane sekwencje walki, będące nieodłącznym elementem sword and sorcery, są tu zatem istotnym czynnikiem dynamizującym fabułę. Można zauważyć, że opis często nie tyle koncentruje się na zaprezentowaniu śmierci, ile raczej podąża za ruchami bohatera. Te jednak pozostają nieuchwytne dla pozostałych uczestników starcia, a zatem również dla czytelnika, któremu całe zajście zostaje przedstawione właśnie z perspektywy tych, którzy stają przeciw wiedźminowi. W taki sposób został skomponowany opis zdarzenia z miejscowości Blaviken, które zapewniło Geraltowi niechlubne miano rzeźnika:

Tavik był pierwszy. Jeszcze niedawno ścigał wiedźmina, teraz nagle dostrzegł, że ten mija go z lewej strony, biegnąc w przeciwnym kierunku. Zadrobił nogami, by wyhamować, ale wiedźmin przemknął obok, nim zdążył unieść miecz. Tavik poczuł silne uderzenie tuż ponad biodrem. Odkręcił się i stwierdził, że pada. Już na kolanach, zdziwiony spojrzał na swoje biodro i zaczął krzyczeć.

Bliźniacy jednocześnie atakując pędzący na nich czarny, rozmazany kształt, wpadli na siebie, zderzyli się barkami, na moment tracąc rytm. Wystarczyło. Vyr, cięty przez całą szerokość piersi, zgiął się wpół, z opuszczoną głową zrobił jeszcze parę kroków i runął na stragan z warzywami. Nimir dostał w skroń, zawirował w miejscu i padł do rynsztoka, ciężko, bezwładnie ${ }^{17}$.

W przytoczonym fragmencie decydującą rolę odgrywa podkreślenie dynamiki zdarzeń, wpisującej się w tok narracji przygodowej. Uwagę zwracają takie określenia, jak: ,jeszcze niedawno”, „nagle”, ,jednocześnie”, „na moment”, które wskazują na koincydencję zdarzeń, podkreślają, iż wszystko dzieje się nagle, niespodziewanie i nawet (czy raczej — zwłaszcza) chwilowa nieuwaga może przesądzić o losie postaci. Ponadto ukazanie starcia przede wszystkim przez pryzmat doświadczeń walczących z wiedźminem członków zbójeckiej bandy oraz uwypuklenie ich reakcji sprawia, że wydają się oni bardziej „realni”, jakby „namacalni”, podczas gdy Geralt jedynie „przemyka obok” lub jawi się jako „pędzący [...] czarny, rozmazany kształt". Protagonista niemal znika z tego fragmentu narracji jako postać, stając się nieuchwytnym zagrożeniem, którego ruch można śledzić jedynie o tyle, o ile można dostrzec jego efekty — obrażenia zadane przeciwnikom. Pokazuje to również, że pewne zdarzenia mają miejsce niejako poza percepcją zmysłów. Skupienie uwagi na reakcjach ginących jeden po drugim rozbójników z jednej strony

16 Na temat schematów literatury przygodowej i ich dekonstrukcji w cyklu wiedźmińskim zob. J. Płoszaj, Przygody pewnego wiedźmina. Konstrukcja i destrukcja schematów fabularnych w opowiadaniach Sapkowskiego, [w:] Wiedźmin — polski fenomen popkultury, red. R. Dudziński, J. Płoszaj, Wrocław 2016, http://tricksterzy.pl/download/wiedzmin-polski-fenomen-popkultury/ (dostęp: 31.01.2020).

17 A. Sapkowski, Mniejsze zło, [w:] idem, Ostatnie życzenie, Warszawa 2001, s. 112-113. Wszystkie wyróżnienia w tekście — jeśli nie zaznaczono inaczej — pochodzą ode mnie. 
oddaje ich zagubienie w starciu z nieznanym dotąd i nieuchwytnym zagrożeniem; z drugiej - wskazanie tych punktów na ich ciałach, których dosięgają precyzyjnie wymierzone cięcia, podkreśla instynktowne działanie wiedźmina i stanowi element charakterystyki postaci w pierwszych tekstach należących do cyklu.

Opis masakry w Blaviken nie jest odosobnionym przypadkiem, Sapkowski podobnymi zabiegami dynamizującymi akcję posługuje się bowiem w całym cyklu wielokrotnie. Innym przykładem podobnej kompozycji jest opis walki, do której Ciri zostaje zmuszona przez Bonharta na arenie w Claremont:

Wydawało mu się, że odwrócona do niego plecami dziewczyna jest rozkojarzona, zdekoncentrowana. Wrzał z gniewu, wstydu, nienawiści. I nie wytrzymał. Zaatakował. Szybko i zdradziecko.

Widownia nie zauważyła uniku i odwrotnego ciosu. Zobaczyła tylko, jak rzucający się na Falkę Stavro wykonuje nagle iście baletowy podskok, po którym w mało baletowy sposób pada brzuchem i twarzą w piach, a piach momentalnie nasiąka krwią ${ }^{18}$.

Mimo że jest to zaledwie początek znacznie dłuższego opisu, już tutaj można zaobserwować elementy, które na poziomie kompozycyjnym łączą go z analizowaną wcześniej deskrypcją masakry w Blaviken: przeniesienie uwagi na postać walczącą z protagonistką, ukrycie w toku narracji samej bohaterki, której ruchy manifestują się poprzez obrażenia zadawane przeciwnikowi, skupienie uwagi na reakcjach zranionego ciała. Tutaj nieuchwytność ruchów Ciri zostaje podkreślona ponadto przez wskazanie tego, co śledzi wzrok osób znajdujących się na widowni: nie ruch bohaterki, ponieważ ten — zbyt szybki — umyka percepcji zmysłów, lecz ruch i reakcję ciała jej przeciwnika, doznającego obrażeń w wyniku niedostrzegalnych cięć.

W obu przypadkach uwagę zwraca również znaczna liczba czasowników, budowanie opisu na podstawie krótkich, często urywanych zdań czy też równoważników zdań („Piętnastka obrócił się szybko. Nie dość szybko”; „Podrywając się, złożył paradę, za wolno”; „Upadł na klęczki, potrząsnął głową, chciał wstać, nie zdołał”19; „Stavro uniósł się na drgających z wysiłku ramionach, zaszamotał głową, zakrzyczał, zachrypiał, rzygnął krwią i opadł na piasek"20), które dodatkowo podkreślają dynamikę zaprezentowanej sceny. Narracja stara się podążać za szybkimi działaniami bohaterów, może jednak uchwycić tylko ich efekty (które uwidoczniają się na ciałach dosięgniętych cięciem wiedźmińskiego miecza) - te z kolei zostają uwypuklone opisem biologicznych i fizjologicznych konsekwencji doznanych obrażeń. Dynamika zdarzeń nie pozostawia tu miejsca na refleksję na temat śmierci: narracja skupia się na efektach działań protagonistów, zgon natomiast jest ich prostą konsekwencją. Wydaje się ona tak oczywista, że sam moment konania zostaje usunięty poza ramy narracji — postać znika z niej w momencie otrzymania decydującego ciosu, nie zaś w chwili zgonu, który zostaje ukryty przed

18 A. Sapkowski, Wieża Jaskółki, Warszawa 2001, s. 153.

19 A. Sapkowski, Mniejsze zło, s. 113.

20 A. Sapkowski, Wieża..., s. 154. 
wzrokiem czytelnika starającego się nadal śledzić nieuchwytny ruch głównego bohatera (lub bohaterki). Widoczne są tu echa ludycznej funkcji, jaką pełnią deskrypcje śmierci w fantasy przygodowej ${ }^{21}$. Idąc dalej, można również zauważyć, że kompozycja wspomnianych opisów, a zatem podążanie za ruchem protagonisty, wyeksponowanie ran i usunięcie poza ramy narracji postaci, która otrzymała ostateczny cios, przywodzi na myśl sekwencje montażowe charakterystyczne dla filmów akcji, gdy oko kamery także śledzi działania głównego bohatera, podczas gdy jego zneutralizowani przeciwnicy są usuwani poza kadr. W takim ujęciu akt odebrania życia zazwyczaj zostaje pozbawiony ciężaru moralnego i emocjonalnego, co zauważa Louis-Vincent Thomas między innymi na przykładzie westernu (również gatunku przygodowego), podkreślając, że wszechobecność śmierci znieczula na nią: „Ludzie padają na lewo i prawo, ale nie umierają. [...] Śmierć nie istnieje ani jako fakt fizjologiczny, ani jako wartość tragiczna"22.

Charakterystyczna dla sword and sorcery dynamika opisów (pełniąca podobne funkcje jak zabiegi montażowe w filmach akcji) sprawia, że uwagę przykuwa tu przede wszystkim efektowność całej sekwencji walki, sama śmierć zostaje jej natomiast podporządkowana $\mathrm{i}$ wykorzystana instrumentalnie $\mathrm{w}$ ramach przygodowej dynamiki. W odniesieniu do twórczości Sapkowskiego Małgorzata Tkacz zauważa:

Tego rodzaju sceny [efektowne opisy walk - J.P.] otrzymały stałe miejsce w polskiej fantasy, której autorzy prześcigają się często w plastyce ich przedstawiania, a niejednokrotnie sprawiają, że prezentowane okrucieństwo i makabra przekraczają granice dobrego smaku, podszyte bywają niewybrednym seksualizmem $[\ldots]^{23}$.

Warto jednak podkreślić, że opinia ta, o ile dość trafnie oddaje to, w jaki sposób obrazowane są śmierć i przemoc w późniejszych utworach polskiej literatury fantasy, o tyle do cyklu wiedźmińskiego odnosi się dość powierzchownie. Ujawnia jednak siłę oddziaływania skomponowanych przez Sapkowskiego opisów śmierci, przez których pryzmat postrzegane są analogiczne deskrypcje prezentowane przez innych autorów. Tkacz zwraca bowiem uwagę wyłącznie na jeden aspekt: makabrę, w którą rzeczywiście obfituje twórczość wielu czołowych autorów polskiej literatury fantasy, na przykład Feliksa W. Kresa, Jarosława Grzędowicza, Jacka Piekary czy Andrzeja Ziemiańskiego. Deskrypcje śmierci i przemocy w cyklu o wiedźminie zdecydowanie wyróżniają się jednak na tym tle, a wpływa na to właśnie zaprezentowana już dynamika opisu. Warto bowiem podkreślić, że w innych cyklach znanych z brutalnej kreacji świata przedstawio-

21 Na temat obrazowania oraz znaczenia śmierci w fantasy przygodowym zob. J. Płoszaj, Między wzniostościa a upodleniem. Obrazowanie oraz znaczenie śmierci w fantasy przygodowej i mitopoetyckiej, „Literatura i Kultura Popularna” 23, 2017, s. 77-83.

${ }^{22}$ L.V. Thomas, Doświadczanie śmierci: jego granice i rzeczywistość, [w:] Antropologia śmierci. Myśl francuska, red. S. Cichowicz, J.M. Godzimski, przeł. S. Cichowicz, J.M. Godzimski, wstęp S. Cichowicz, Warszawa 1993, s. 176.

23 M. Tkacz, op. cit., s. 71. 
nego makabra zwykle ukazywana jest w sposób statyczny, a opis koncentruje się przede wszystkim na drobiazgowym ukazaniu naznaczonego przemocą ciała lub trupa $\mathrm{w}$ zaawansowanym stadium rozkładu, tym samym skupiając na nim całą uwagę odbiorcy ${ }^{24}$.

\section{Śmierć zindywidualizowana}

Mimo zachowania przygodowej dynamiki opisu Sapkowskiemu udaje się uniknąć typowego dla sword and sorcery czysto instrumentalnego wykorzystania wprowadzonych do fabuły scen przemocy oraz śmierci ${ }^{25}$. Dzieje się tak, ponieważ łódzki autor traktuje poszczególne postaci w narracji jednostkowo $\mathrm{w}$ chwili śmierci nie podlegają one depersonalizacji, jak miało to miejsce w kanonicznych utworach fantasy przygodowej. Edgar Morin zauważa: „tam, gdzie śmierć nie jest zindywidualizowana, jest tylko obojętność [...]. Przestajemy się bać, gdy mamy do czynienia ze zwierzęcym ścierwem lub ze zwłokami wroga czy zdrajcy"26. Ludzie według niego boją się nie trupa jako takiego, lecz trupa, który jest do nich podobny. Sapkowski zwykle unika w opisie dystansujących metafor, które odbierałyby ginącym postaciom antropomorficzny kształt. Zamiast tego wymienia umierających z imienia, podkreślając $\mathrm{w}$ ten sposób, iż nie są oni bliżej nieokreślonymi bytami, sprowadzonymi jedynie do funkcji fabularnej, co — mimo przygodowej dynamiki opisu — nie pozwala całkowicie zdystansować się względem prezentowanej śmierci.

Sapkowski umiejętnie zwalnia dynamikę opisu tam, gdzie służy to wzmocnieniu dramaturgii. Tak właśnie zaprezentowana jest śmierć towarzyszy Geralta na zamku Stygga w trakcie próby uwolnienia Yennefer i Ciri z rąk Vilgefortza. Scena - a właściwie sekwencja dynamicznie przechodzących w siebie scen wyróżnia się zastosowaniem retardacji w formie wspomnień ginących postaci.

${ }^{24}$ Temat ten analizuję szerzej w tekstach: J. Płoszaj, Bezsilne ciała. Uwagi na temat przemocy przedstawionej w cyklu inkwizytorskim Jacka Piekary, [w:] Literatura i kultura popularna. Między tradycją a nowatorstwem, red. A. Gemra, Wrocław 2016; eadem, Przerażająco krwawe światy... Groza śmierci w polskiej literaturze fantasy na przykładzie twórczości Jacka Piekary i Andrzeja Ziemiańskiego, [w:] Światy grozy, red. K. Olkusz, Kraków 2016, https://depot.ceon.pl/bitstream/handle/1234 56789/10227/\%C5\%9Awiaty\%20grozy\%20-\%20do\%20dystrybucji.pdf?sequence=1\&isAllowed=y (dostęp: 31.01.2020).

${ }^{25} \mathrm{~W}$ tradycyjnych realizacjach fantasy przygodowej nagromadzenie obrazów śmierci ma przede wszystkim znaczenie fabularne i pełni funkcje na poziomie samej konstrukcji utworów — służy dynamizowaniu akcji, wprowadzaniu bądź rozwiązywaniu kolejnych wątków awanturniczych, a także jest istotnym elementem charakterystyki protagonisty, wskazując na jego sprawność i siłę fizyczną. Zob. J. Płoszaj, Między wzniosłością..., s. 83, 91.

26 E. Morin, Antropologia śmierci, [w:] Antropologia śmierci, s. 86. O zaistnieniu podobnej zależności w związku z literackimi przedstawieniami śmierci lub zwłok pisze także Ryszard Koziołek w swojej wnikliwej analizie obrazów przemocy i okrucieństwa w twórczości Henryka Sienkiewicza. Zob. R. Koziołek, Popisy przemocy, [w:] idem, Ciała Sienkiewicza, Wołowiec 2018. 
Podkreśla to indywidualizację śmierci poszczególnych bohaterów, retrospekcje nawiązują bowiem do samego momentu śmierci - łuczniczka Milva wspomina naukę pod okiem ojca tuż przed tym, gdy sama zostaje przeszyta strzałą przeciwnika; rycerz Cahir natomiast, oddając życie za Ciri — cintryjską księżniczkę — przypomina sobie moment, w którym jego starszy brat zginął podczas starć z królestwami Północy ${ }^{27}$. Chwila nostalgii, która odkrywa przed czytelnikiem fragment historii postaci, daje odbiorcy możliwość utożsamienia się z bohaterem, lepszego zrozumienia jego motywacji i wagi dokonywanych wyborów. Jednocześnie stanowi ona de facto moment pożegnania postaci, a przerwana zostaje nagłym narracyjnym przejściem wprost do szokującego opisu gwałtownej i drastycznej śmierci.

Charakterystycznym w twórczości Sapkowskiego zabiegiem jest również swobodne przejście między dynamicznym podążaniem za ruchem protagonisty a momentami ekspozycji, pozwalające wyjść poza typowe funkcje przypisane opisom śmierci w narracji awanturniczej. Można to zauważyć na przykładzie starcia wiedźmina z rozbójniczką Renfri podczas wspomnianych wcześniej wydarzeń w Blaviken. W dynamicznej sekwencji walki między wiedźminem a pozostałymi członkami zbójeckiej bandy już samo wymienienie ich z imienia tuż przed śmiercią wykraczało poza typowy schemat podobnych opisów, które można odnaleźć w fantasy przygodowej, jednak dopiero śmierć Renfri jest w pełni zindywidualizowana i ukazana jednostkowo. Wyróżnia ją choćby sposób, w jaki bohaterka zostaje wprowadzona przez narratora tuż przed śmiertelnym starciem:

Na rynek weszła Renfri.

Nadchodziła wolno miękkim, kocim krokiem, wymijając wózki i stragany. Tłum, który w uliczkach i pod ścianami domów buczał jak rój szerszeni, ścichł. Geralt stał nieruchomo z mieczem w opuszczonej dłoni ${ }^{28}$.

Spowolnienie akcji oraz skupienie uwagi odbiorcy wyłącznie na Renfri kontrastuje z wcześniejszym bardzo dynamicznym opisem, a jednocześnie przynosi chwilowe fabularne wyciszenie, poprzedzające niejako „starcie gigantów” (częsty zresztą w tekstach kultury popularnej zabieg eksponujący moment, gdy antagoniści stają naprzeciw siebie ${ }^{29}$. Warto również podkreślić, że gdy walka już się roz-

27 Zob. A. Sapkowski, Pani Jeziora, Warszawa 2001, s. 346-348, 362-364.

28 A. Sapkowski, Mniejsze zło, s. 113.

29 Schemat związany z ekspozycją stających naprzeciw siebie antagonistów tuż przed decydującym starciem został funkcjonalnie przejęty z westernu. W wypadku twórczości Sapkowskiego nie jest to zresztą jedyne westernowe zapożyczenie — jest nim również sposób wprowadzenia głównego bohatera w Wiedźminie jako Obcego, ,jeźdźca znikąd”, a w późniejszych opowiadaniach — wprowadzenie postaci polegające na odkrywaniu śladów jej charakterystycznego nacechowania, dające czytelnikowi zaznajomionemu z poprzednimi przygodami bohatera przyjemność jego ponownego rozpoznania. Szerzej na ten temat pisze Michał Rogoż, Pomiędzy konwencja a mimesis różne wymiary świata przedstawionego w opowiadaniach Andrzeja Sapkowskiego Ostatnie życzenie $i$ Miecz przeznaczenia, [w:] Fantastyczność i cudowność. Wokót źródel fantasy, red. B. Trocha, T. Ratajczak, Zielona Góra 2009, s. 236. 
poczyna, ma ona odmienną dynamikę niż ta, w której zginęli towarzysze Renfri. O ile bowiem wcześniej czytelnik mógł jedynie podążać w narracji za nieuchwytnymi ruchami wiedźmina, o tyle teraz ma wrażenie starcia dwojga niemal równorzędnych wojowników: opis raz skupia się na Geralcie, raz na Renfri, płynnie przechodząc pomiędzy nimi; jest nie tylko dynamiczny, ale i zbalansowany pod względem uwagi poświęcanej bohaterom biorącym udział w walce. Równowaga jest jednak pozorna, na co wskazuje gwałtowne przerwanie sekwencji w chwili wyprowadzenia przez Geralta śmiertelnego cięcia.

Zgon Renfri zostaje wyeksponowany na tle wcześniejszej przygodowej dynamik zdarzeń. Narracja zwalnia, pozwalając, by moment śmierci nabrał refleksyjnego charakteru:

Renfri jęknęła znowu, kuląc się jeszcze bardziej. Krew wartkimi strumyczkami wypełniała jamki między kamieniami.

- Geralt... Obejmij mnie...

Nie odpowiedział.

Odwróciła głowę i znieruchomiała z policzkiem na bruku. Sztylet o bardzo wąskim ostrzu, do tej pory skrywany pod ciałem, wyśliznął się z jej martwiejących palców.

Po chwili będącej wiecznością wiedźmin uniósł głowę na odgłos stukającej o bruk różdżki Stregobora ${ }^{30}$.

Spowolnienie tempa narracji oraz skoncentrowanie uwagi na umierającej Renfri pozwala zarówno na refleksję związaną ze śmiercią postaci, jak i na ekspozycję towarzyszących jej emocji. Mimo iż nie zostają one nazwane wprost, czytelnik bardzo wyraźnie może odczuć ciężar podjętej przez wiedźmina decyzji o walce z Renfri i jej towarzyszami w obronie mieszkańców Blaviken (spotęgowany tym, że rozbójniczka wprost przyznała, że nie wprowadziłaby w życie morderczych gróźb), a także determinację umierającej, gotowej walczyć aż do ostatniego tchu. Emocjonalny wydźwięk sceny jest tak mocny, że pojawienie się w miejscu walki czarodzieja Stregobora (pośrednio również sprawcy całego zajścia), przerywające refleksyjną chwilę, wydaje się wręcz niestosowne. Dramaturgia opisu — z jednej strony oszczędnego w słowach, z drugiej zaś niezwykle emocjonalnego - nie pozostawia miejsca na dystans względem prezentowanej sceny. Dzięki temu Sapkowskiemu udaje się w ramach narracji przygodowej wyjść poza typowe funkcje, jakie zwykle pełnią literackie obrazy śmierci i przemocy w fabułach awanturniczym.

\section{Śmierć w detalu}

Spowolnienie dynamiki nie tylko powala na indywidualizację scen śmierci, ale też zwraca uwagę na kolejną ważną cechę omawianych opisów, czyli na istotną rolę, jaką odgrywa w nich zaakcentowanie detalu. Niejednokrotnie puentę de-

30 A. Sapkowski, Mniejsze zło, s. 115. 
skrypcji śmierci tworzy krótkie, dobitne zdanie lub jego równoważnik — czasami jedno słowo - eksponujące makabryczny szczegół i ogniskujące na nim uwagę odbiorcy. Sapkowski korzysta z tego zabiegu już na początkowym etapie swojej twórczości, wprowadzając go po raz pierwszy w opowiadaniu Ziarno prawdy, drugim tekście opublikowanym ramach cyklu o wiedźminie:

Uderzył płynnie, jak setki razy przedtem, środkiem brzeszczotu [...]. Klinga, pod koniec półobrotu już wolna, sunęła za nim błyszcząc, wlokąc za sobą wachlarzyk czerwonych kropelek. Kruczoczarne włosy zafalowały rozwiewając się, płynęły w powietrzu, płynęły, płynęły...

Głowa upadła na żwir ${ }^{31}$.

Przytoczony fragment to zwieńczenie walki Geralta z wampirzycą (bruxą) Vereeną. W chwili decydującego cięcia narracja przechodzi tu od niezwykle dynamicznego, charakterystycznego dla literatury przygodowej opisu starcia („Poderwał się z ziemi, błyskawicznie dopasowując tempo ruchów do prędkości lotu potwora wykonał trzy kroki w przód, unik i półobrót, a po nich szybki jak myśl, oburęczny cios”; „Geralt [...] skoczył ku niej, ale reakcje wampirzycy były znacznie szybsze") $)^{32}$, ku stopniowemu spowolnieniu tempa aż po dosadną puentę definitywnie kończącą ruch. Podkreśla to dobór środków językowych, którymi posługuje się autor - początkowo narracja śledzi poczynania walczących postaci, uwypuklając przede wszystkim ich nadnaturalną prędkość i gwałtowne zmiany sytuacji; moment wymierzenia ostatecznego cięcia jest jednocześnie tym, który zmienia dynamikę i optykę opisu. Uwaga odbiorcy zostaje skupiona wokół detali (kropelki krwi, czarne włosy), nie zaś na całościowym obrazie makabrycznego zgonu. Płynne spowolnienie akcji podkreśla dobór czasowników („sunęła”, „wlokąc”, „zafalowały”, „płynęły”) — następuje wygaszenie dominującego wcześniej ruchu. Ostatecznie jednak zamknięcie dynamicznej sekwencji dokonuje się bardzo wyraźnie i gwałtownie: krótkim, pojedynczym zdaniem wyeksponowanym w osobnym akapicie, skupiającym całą uwagę odbiorcy na odciętej głowie wampirzycy i niepozwalającym zapomnieć o obecności martwego, zdekapitowanego ciała.

Podobnie skomponowany jest opis starcia Ciri z jej wcześniejszymi oprawcami w Wieży Jaskółki:

Zgrzyt łyżew usłyszeli w ostatnim momencie. Dziewczyna nadjeżdżała z niesamowitą prędkością, wręcz rozmazywała się w oczach. Nadjeżdżała samym skrajem kry, mknęła tuż przy krawędzi.

Rience wrzasnął. I zachłysnął się gęstą, ołowianą wodą. I zniknął.

$\mathrm{Na}$ krze, na równiutkim śladzie łyżwy, została krew. I palce. Osiem palców ${ }^{33}$.

\footnotetext{
31 A. Sapkowski, Ziarno prawdy, [w:] idem, Ostatnie życzenie, s. 71.

32 A. Sapkowski, Mniejsze zło, s. 69.

33 A. Sapkowski, Wieża..., s. 420.
} 
Można tu zauważyć, że ponownie w momencie zgonu umierający antagonista znika z narracji — nie tylko jako jedna z postaci. Znika również jego ciało, pozostawiając po sobie jedynie makabryczny szczegół: osiem odciętych łyżwami palców, którymi Rience kurczowo trzymał się kry, a co za tym idzie — również życia.

Na podobną fabularną i emocjonalną funkcjonalność zdekomponowania ciała postaci w chwili śmierci wskazał Ryszard Koziołek, analizując literackie obrazy śmierci i przemocy w twórczości Henryka Sienkiewicza. Zauważył on, że zaprezentowanie w narracji postaci w momencie zgonu bądź tuż przed nim nie całościowo, lecz jako pewien zbiór elementów sprzyja tworzeniu emocjonalnego dystansu względem prezentowanego okrucieństwa ${ }^{34}$. Sapkowski nigdy nie ukrywał fascynacji prozą Sienkiewicza, echa wypracowanej przez niego poetyki opisu przemocy można więc w cyklu wiedźmińskim odnaleźć bez trudu. Autor trylogii husyckiej niejednokrotnie jednak przewartościowuje zaczerpnięte od Sienkiewicza elementy narracyjne ${ }^{35}$, zmieniając tym samym ich wymowę. Również w zaprezentowanych fragmentach, wykorzystując podobny zabieg kompozycyjny, Sapkowski przewrotnie nadaje obu deskrypcjom inny wydźwięk emocjonalny, wynikający z relacji między uczestniczącymi w opisie postaciami. Mimo że w momencie śmierci Vereena zostaje ukazana jako zbiór zdekomponowanych elementów (krople krwi, falujące włosy, głowa), co ukrywa przed oczami czytelnika chwilę zgonu, odbiorcy trudno pozostać na ten fakt obojętnym. Ładunek emocjonalny sceny wiąże się bowiem z zawartym w opowiadaniu wątkiem tragicznej (i niebezpiecznej) miłości pomiędzy bruxą a dotkniętym klątwą człowiekiem Nivellenem, nieświadomym dotąd prawdziwej tożsamości swojej wybranki. Wieńczące opis zdanie wyznacza zatem nie tylko kres życia wampirzycy, ale też łączącej ją z Nivellenem relacji.

Nieco inną wymowę niesie z sobą natomiast śmierć Rience'a, który w Krwi elfów - pierwszej części powieściowego pięcioksięgu — pojawia się jako jeden z głównych antagonistów. Koziołek podkreśla, że z fabularnego punktu widzenia bardziej skuteczne jest przedstawianie przemocy i okrucieństwa postaci negatywnej niż protagonisty, ponieważ „ten pierwszy niszczy wyjściowy ład [...], wyrywa stamtąd bohatera i usprawiedliwia jego akty przemocy" ${ }^{36}$. Słowa te znajdują odzwierciedlenie w przytoczonym fragmencie powieści: zbrodnie, których dopuszczał się Rience w całym cyklu, a także krzywdy, jakich doznała Ciri, wpływają na to, iż jej zemsta na oprawcach postrzegana jest jako słusznie wymierzona sprawiedliwość i z tego powodu staje się źródłem satysfakcji odbiorcy.

34 R. Koziołek, op. cit., s. 345.

35 Mechanizmy te omawiam szczegółowo w pracy poświęconej drugiemu z najbardziej popularnych literackich cykli Sapkowskiego. Zob. J. Płoszaj, ,, W walce o stuszna sprawę nie ma etyki”. Funkcje i sposoby przedstawiania przemocy w trylogii husyckiej Andrzeja Sapkowskiego, [w:] Stowiańszczyzna dawniej i dziś - język, literatura, kultura. Monografia ze studiów slawistycznych III, red. A. Kołodziej, współp. T. Piasecki, Červený Kostelec 2017.

${ }^{36}$ R. Koziołek, op. cit., s. 346-347. 
Mimo istotnej roli, jaką w opisach śmierci w cyklu o wiedźminie odgrywa detal, w twórczości Sapkowskiego do rzadkości należą dokładne deskrypcje zwłok oraz obrażeń widocznych na martwym już ciele ${ }^{37}$. Waga szczegółu ujawnia się tutaj nie w makabrycznej drobiazgowości, lecz właśnie w zaakcentowaniu detalu, który najmocniej przykuje uwagę odbiorcy, wyróżniając dany opis na tle innych. Dochodzi tu zatem do pewnego paradoksu. Jak zauważył Koziołek, w literaturze przedstawienie naznaczonego przemocą ciała jako zdeantropomorfizowanego zbioru elementów sprzyja wytworzeniu u odbiorcy emocjonalnego dystansu względem prezentowanego okrucieństwa. Sapkowski tymczasem, przenosząc uwagę z dynamicznego ujęcia ruchu na statycznie wyeksponowany detal ciała, znosi dystans, gwałtownie przełamując przygodową dynamikę opisu. W tym wypadku zaakcentowany szczegół niesie z sobą przekaz mocniejszy niż drobiazgowa deskrypcja trupa, natomiast balansowanie między dynamiką a statycznością w opisie wpływa na jego uplastycznienie. Dobitna puenta pozwala uchwycić moment śmierci i podkreśla towarzyszące mu emocje. W przypadku Vereeny jest to nagła pustka po stracie kogoś bliskiego zarówno w sensie dosłownym (śmierć), jak i przenośnym (konfrontacja rzeczywistości z wyobrażeniami na temat kogoś znanego tylko pozornie); w przypadku zaś Rience'a z jednej strony strach przed śmiercią, z drugiej natomiast - nienawiść i satysfakcja płynąca z dokonanej zemsty.

\section{Śmierć wieloperspektywiczna}

Opisy śmierci w cyklu wiedźmińskim najczęściej prezentowane są w narracji trzecioosobowej, ta jednak często przyjmuje perspektywę różnych postaci — również tych, które nie są bezpośrednio związane z główną linią fabularną, ale stają się obserwatorami dramatycznych zdarzeń lub ich mimowolnymi uczestnikami. Dzięki temu czytelnik odbiera sytuację nie w narracji zobiektywizowanej, a przez pryzmat odczuć postaci, która - często przypadkowo — znalazła się w centrum akcji. Doskonale oddaje to zaprezentowanie walki w karczmie z punktu widzenia ukrytego pod stołem dziada:

Na stół ktoś runął, przesuwając mebel wraz z uczepionym dziadem, zwalił się obok na podłogę. Dziad zaryczał, czując, jak bryzga na niego gorąca krew. [...]

Ktoś z hukiem rymnął na podłogę, znowu po świeżo wymytej sośninie desek podłogi rozbryzgnęła się krew. Dziad nie poznał, że tym, który właśnie umierał, był Rispat La Pointe,

37 Takie opisy często pojawiają się w twórczości innych polskich autorów fantasy. Chętnie inkrustuje nimi fabułę między innymi Jacek Piekara w cyklu inkwizytorskim, obfitującym w podobne deskrypcje zmasakrowanych ciał: „Ciało zamordowanej leżało pod ścianą. Głow a wy gięta była pod nienaturalnym kątem i dopiero po chwili zorientowałem się, że oprawca niemal oderżnął tę głowę od tułowia. [...] Morderca zdarł z niej niemal całą skórę, pozostawiając jedynie zakrwawioną maskę, nieprzypominającą już nawet ludzkiego oblicza" (idem, Dziewczyny rzeźnika, [w:] idem, Ja, inkwizytor. Wieże do nieba, Lublin 2013, s. 5-6). 
cięty przez Ciri w bok szyi. Nie widział, jak Ciri wykręciła piruet tuż przed nosami Fripa i Janowitza, jak przeszła przez ich zastawy jak cień, jak szary dym ${ }^{38}$.

Przyjęcie takiej perspektywy narracyjnej daje obraz niepełny, fragmentaryczny, co z jednej strony trafnie oddaje panujący w pomieszczeniu chaos, $\mathrm{z}$ drugiej zaś sprawia, że obraz zostaje nacechowany emocjami towarzyszącymi postronnym uczestnikom zdarzeń - w tym wypadku przede wszystkim zagubieniem, strachem, wolą przetrwania. Dzięki temu można zauważyć, że zaprezentowany opis walki charakteryzuje się inną niż dotychczas dynamiką, nie wynika ona bowiem z podążania za ruchem protagonisty, lecz właśnie ze wspomnianej fragmentaryczności. Drastyczne obrazy pojawiają się nagle w polu widzenia ukrytego pod stołem, zachlapanego cudzą krwią człowieka, który nie wszystko może dostrzec z zajmowanej przez siebie pozycji, lecz domyśla się tego na podstawie dochodzących go przerażających odgłosów. Pozwala to również spojrzeć jego oczami na protagonistkę, gdy zwraca się do niej: „Kto się z tobą spotka [...] ten już nie odejmie śmierci... Boś ty sama jest śmiercią"39. Zmiana perspektywy narracyjnej znosi na moment wspomniane wcześniej fabularne usprawiedliwienie przemocy motywowanej zemstą, wskazuje bowiem, że akty okrucieństwa nie funkcjonują w układzie odizolowanym i zawsze mają swoje konsekwencje, które mogą dotknąc przypadkowe osoby.

Innym przykładem ukrycia śmierci przed wzrokiem czytelnika za pomocą perspektywy narracyjnej jest fragment opowiadania Granica możliwości:

Kozojed pomykał jak jeleń, ale smok był szybszy. Geralt, widząc rozwierającą się paszczę i błyskające zęby, ostre jak sztylety, odwrócił głowę. Usłyszał makabryczny wrzask i obrzydliwy chrzęst. Jaskier krzyknął zduszonym głosem. Yennefer, z twarzą białą jak płótno, zgięła się w pół, wykręciła w bok i zwymiotowała pod wóz ${ }^{40}$.

Narracja przyjmuje tu punkt widzenia protagonisty, który w kluczowym momencie odwraca głowę. Sapkowski rezygnuje z opisu wizualnych aspektów prezentowanej sceny; nie znaczy to jednak, że staje się ona mniej drastyczna, o skali makabry zaświadczać mogą bowiem gwałtowne reakcje Jaskra i Yennefer. Ukazanie momentu śmierci w perspektywie percepcji innych zmysłów, takich jak słuch czy węch, pozwala na zróżnicowanie opisów, które nie są dzięki temu jednowymiarowe, prezentują śmierć wieloaspektowo i nie koncentrują się wyłącznie na obrazowych walorach makabry.

Przejścia narracyjne wpływają również na dramatyczny wydźwięk sceny ukazującej śmierć Szczurów (zbójeckiej bandy, która otoczyła opieką Ciri po tym, jak uszkodzony portal teleportacyjny przeniósł ją w samo serce wrogiego Cesarstwa

38 A. Sapkowski, Wieża..., s. 388. Pojawia się tu kolejny problem związany również z prefiguracją śmierci oraz jej zwiastunami w cyklu wiedźmińskim. Szerzej na ten temat zob. A. Moroz, Jak uwieść czytelnika? Jonathan Carroll i Andrzej Sapkowski wobec kulturowych koncepcji śmierci, Warszawa 2014, s. 56-71.

39 A. Sapkowski, Wieża.., s. 390.

40 A. Sapkowski, Granica możliwości, [w:] idem, Miecz przeznaczenia, Warszawa 2001, s. 75. 
Nilfgaardu) z rąk bezlitosnego łowcy głów Bonharta. Akcja rozgrywa się w retrospekcjach prezentowanych w narracji trzecioosobowej, a wyjątkowo brutalny opis zawiera właściwie wszystkie omówione dotąd cechy deskrypcji śmierci w cyklu wiedźmińskim: indywidualizuje śmierć każdej z postaci, eksponuje najbardziej sugestywne detale i jest bardzo dynamiczny — krótkie, proste zdania z jednej strony podkreślają błyskawiczne tempo zdarzeń, z drugiej zaś — oddzielają od siebie poszczególne elementy sekwencji, zamykając je w klamrach kompozycyjnych („A potem, nagle i niespodziewanie, Szczury zaczęly krzyczeć. I umierać”; „A Szczury cofały się. I umierały”; „Znaleźli śmierć”) ${ }^{41}$. Jest niezwykle obrazowy i można powiedzieć, że stanowi wręcz kwintesencję wypracowanej przez Sapkowskiego poetyki opisu scen śmierci. Widowiskowa dynamika opisu, nagromadzenie brutalnych szczegółów i zaprezentowanie ich w trzecioosobowej, zobiektywizowanej narracji sprzyja wytworzeniu emocjonalnego dystansu względem prezentowanego okrucieństwa. Retrospekcja urywa się jednak wraz z rozstrzygnięciem walki między Bonhartem a Ciri, przenosząc czytelnika do momentu, w którym dziewczyna przybliża swoją historię pustelnikowi Visogocie. Dystans trzecioosobowej narracji zostaje gwałtownie zniesiony w chwili oddania głosu bohaterce. Najdrastyczniejszy fragment opowieści zostaje wprawdzie ukryty przed wzrokiem odbiorcy, lecz przekazany słowami samej Ciri: „Oderżnął im [Szczurom] głowy — powiedziała głucho [...]. — Piłą. [...] Odrzynał im głowy... Po kolei. Na moich oczach"42, niesie z sobą znacznie większy ciężar emocjonalny niż makabryczny w swojej szczegółowości opis. Oddanie głosu bohaterce pozwala wybrzmieć uczuciom, które nią targają, przekazuje ból traumatycznych wspomnień. Dzięki takiej puencie opis nabiera szczególnej wymowy, a efekt ten nie mógłby zostać osiągnięty przy pomocy narracji trzecioosobowej.

\section{Śmieré naturalistyczna}

Wspólną cechą opisów śmierci w cyklu o wiedźminie najmocniej bodaj przykuwającą uwagę jest bez wątpienia częste podkreślanie biologicznych i fizjologicznych aspektów zgonu. Taki sposób obrazowania — częsty również w twórczości innych polskich autorów fantasy - przyczynił się do zarzutów krytyki, jakoby dosłowność obrazowania miała być jedynie apoteozą agresji. Sapkowski w charakterystyczny dla siebie sposób przedstawił jednak funkcje naturalistycznego prezentowania okrucieństwa, odpowiadając Stanisławowi Beresiowi:

naturalizmu żąda gatunek [fantasy — J.P.]. Bajkowe zło zostaje ukarane, a że wcześniej okrucieństwo zła zostało opisane w sposób realistyczny i naturalistyczny, realistyczna i natura-

41 A. Sapkowski, Wieża..., s. 68, 69.

42 Ibidem, s. 73. 
listyczna jest też i kara. A wcześniej Dobro, by móc nad Złem naturalistycznie zatriumfować, musi się naturalistycznie wysilić. $Z$ czasem nawet naturalistycznie pocierpieć ${ }^{43}$.

Słowa te współgrają ze sformułowanymi na podstawie analizy twórczości Sienkiewicza tezami Koziołka na temat fabularnej skuteczności scen przemocy, które generują konsekwentne ciągi zdarzeń. Ponadto dosłowne obrazowanie okrucieństwa antagonistów usprawiedliwia niejako w oczach czytelnika późniejszą bezwzględność głównych bohaterów, a im większych cierpień wcześniej oni doznali, tym większa jest satysfakcja, jaką czerpie odbiorca z brutalnego odwetu, jaki biorą na swoich oprawcach ${ }^{44}$. Warto jednak podkreślić, że o ile słowa te dość trafnie odnoszą się do sytuacji Ciri w Wieży Jaskótki (czy też do bohaterów późniejszej trylogii husyckiej), o tyle drastyczne opisy pojawiały się w cyklu wiedźmińskim właściwie od samego początku i nie zawsze są wpisane we wspomniane ciągi fabularne utworzone wokół krzywdy i zemsty.

Naturalistyczne ujęcie śmierci w twórczości Sapkowskiego nie wynika zatem jedynie z kwestii czysto fabularnych - jak chociażby analizowana wcześniej dynamika opisu — a raczej z dążenia do uprawdopodobnienia rzeczywistości przedstawionej. Łódzki autor ukazuje śmierć w sposób bardzo dosłowny, unikając zwykle ubarwiających, a w szczególności dystansujących metafor. Koncentruje się przede wszystkim na biologicznych aspektach zgonu i fizjologicznych reakcjach organizmu:

Wampirzyca westchnęła rozdzierająco i nagle naparła silnie na kół. Geralt zobaczył, jak na jej plecach, na białej sukni, wykwita czerwona plama, z której w gejzerze krwi wyłazi, ohydnie i nieprzyzwoicie, ułamany szpic. [...] Już przeszło metr skrwawionego drewna wystawał z jej pleców. Oczy miała szeroko otwarte, głowę odrzuconą do tyłu. Jej westchnienia stały się częstsze, rytmiczne, przechodzące w rzężenie ${ }^{45}$.

Opis bez wątpienia jest bardzo obrazowy, na co wpływa zestawienie kolorów (czerwona plama krwi na białej sukni), a hiperbolizująca metafora (,wykwita czerwona plama; „w gejzerze krwi”), mająca podkreślić krwawy aspekt deskrypcji, zostaje szybko zastąpiona naturalistyczną prezentacją przebitego ciała wampirzycy oraz wydawanych przez nią przedśmiertnych odgłosów. Podkreślenie biologicznych aspektów zgonu w tym wypadku nie tylko pełni charakterystyczną dla przedstawień śmierci w literaturze przygodowej funkcję ludyczną, nadając opisowi barwnego i widowiskowego charakteru, ale również, prezentując ciężki, urywany, przechodzący w rzężenie oddech wampirzycy, ukazuje wewnętrzne spustoszenie organizmu i podkreśla towarzyszący temu ból.

Naturalizm opisów śmierci w cyklu o wiedźminie wiąże się jednak nie tylko z ich obrazowością, eksponowaniem drastycznych szczegółów czy podkreślaniem fizjologicznych aspektów zgonu. Przejawia się on także w towarzyszącej śmierci

43 S. Bereś, A. Sapkowski, Historia i fantastyka, Warszawa 2005, s. 34.

44 R. Koziołek, op. cit., s. 346.

45 A. Sapkowski, Ziarno..., s. 70-71. 
scenerii - zawsze jest ona brudna, nieprzyjemna, jak w przypadku opowiadania Mniejsze zło, w którym Renfri umiera na miejskim bruku: „Padając na kolano i na bok, wpiła obie dłonie w przecięte udo. Spomiędzy palców krew zatętniła jasnym strumieniem na ozdobny pas, na łosiowe buty, na brudny bruk"46. Jeszcze dosadniej zostaje to podkreślone w opisie przedstawiającym śmierć Szczurów („Iskra, cięta w tętnicę, padła w błoto”; „Jasnowłosy Szczur upadł, rozbryzgując kałużę krwi zmieszanej z błotem”) ${ }^{47}$ — w szczególności Mistle, z którą Ciri była związana najbliżej:

Mistle, na kolanach, szukała miecza, macała obu rękami błoto i gnój, nie widząc, że klęczy w powiększającej się szybko czerwonej kałuży. [...] Otworzyła usta, by krzyknąć, zamiast krzyku z ust wyrwała się lśniąca, karminowa struga. Bonhart kopnął ją silnie, zwalając w gnój. [...] oczy miała już zamglone, zeszklone, rybie. Jej dłoń, jak jastrzębi szpon, zwierała się i rozwierała, zaryta w błocie i nawozie. Ciri poczuła ostry, przenikliwy odór uryny ${ }^{48}$.

Naturalistyczne wyeksponowanie fizjologicznych aspektów śmierci oraz towarzyszących jej płynów ustrojowych, takich jak krew, śluzy, wszelkiego rodzaju wydzieliny czy nawet fekalia, sprawia, że u Sapkowskiego śmierć przedstawiona jest przede wszystkim w wymiarze biologicznym — umiera organizm. Dosadność deskrypcji zawiera się w jej dosłowności, która nie ukrywa fizjologicznych reakcji ciała w momencie zgonu za zasłoną dystansujących metafor. Dzięki temu w twórczości Sapkowskiego ciało - martwe lub umierające — nie ulega reifikacji, nie zostaje sprowadzone jedynie do roli obiektu, pozwalającego na inkrustowanie fabuły makabrycznymi szczegółami. Nawet gdy dochodzi do jego dezintegracji, nie wiąże się to $\mathrm{z}$ odseparowaniem go od towarzyszących mu wcześniej uczuć, co czyni opisy śmierci w cyklu o wiedźminie bardzo przejmującymi, czasami wręcz wstrząsającymi.

Śmierć w cyklu wiedźmińskim pozbawiona jest również metafizycznego wydźwięku, który towarzyszy jej często w fantasy mitopoetyckiej, wskazując na moralną kondycję umierającej postaci ${ }^{49}$. W swoim czysto biologicznym, naturalistycznym wymiarze nie jest ona też związana z systemem aksjologicznym przedstawionej rzeczywistości — niezależnie od tego, jakie wartości reprezentują postaci, ich śmierć na poziomie organicznym wygląda bardzo podobnie. Nie omija to także Geralta, który właśnie stając w obronie wartości, ginie przebity widłami ${ }^{50}$. Powracające w opisach błoto i odchody, mieszające się z krwią i innymi płynami ustrojowymi, obnażają tu brudną, organiczną naturę śmierci, co trafnie podsumowują słowa Anny Gemry:

Świat Sapkowskiego jest przeraźliwie realny; brak tu gentelmańskich manier Tolkiena, łagodności języka, omijania trudnych tematów, pomijania milczeniem brudu, krwi i łez.

\footnotetext{
46 A. Sapkowski, Mniejsze zło, s. 115.

47 A. Sapkowski, Wieża..., s. 69.

48 Ibidem, s. 69-72.

49 Zob. J. Płoszaj. Między wzniostościa..., s. 84-88.

50 Zob. A. Sapkowski, Pani..., s. 501, 512-513.
} 
[Bohaterowie] cierpią głównie fizycznie, umierają, wyjąc z bólu, są okaleczani, torturowani. Opowieść polskiego pisarza nie jest delikatna, gładka i dobrze wychowana: jest b z y d k o prawdziw a [...] w swoim realizmie, w dosłowności, w brudzie i krwi, w radosnej, nieskrępowanej erotyce, w dosadnym języku, w fizyczności postaci, smrodzie i bólu śmierci ${ }^{51}$.

\section{Śmierć pornograficzna? Podsumowanie}

Różnorodne uwarunkowania fabularne oraz zabiegi narracyjne, którymi posłużył się Sapkowski, komponując literackie obrazy śmierci w cyklu o wiedźminie, składają się na unikalną poetykę tego typu deskrypcji w twórczości łódzkiego autora. Wśród jej najważniejszych cech należy wymienić: konstruowanie opisu na podstawie krótkich, urywanych zdań lub ich równoważników, wprowadzających wyjątkową dynamikę prezentowanej sceny; rezygnację z całościowego, drobiazgowego obrazu na rzecz wyeksponowania najbardziej sugestywnego detalu; budujące napięcie zmiany perspektywy narracyjnej w trakcie prezentowania scen śmierci; zwolnienie dynamiki opisu w celu zindywidualizowania śmierci poszczególnych postaci; naturalistyczne wyeksponowanie biologicznych i fizjologicznych aspektów zgonu. Zależności zachodzące pomiędzy tymi elementami sprawiają, że opisy śmierci w cyklu o wiedźminie stają się bardzo zniuansowane i mimo częstej drastyczności ich estetyka nie daje się sprowadzić jedynie do epatowania okrucieństwem i makabrą, co bywa częste w twórczości innych popularnych polskich autorów fantasy.

Pewne cechy opisów śmierci w cyklu wiedźmińskim, w szczególności charakterystyczna dla fantasy przygodowej widowiskowa dynamika sekwencji walki poprzedzających zgon czy też krwawe, brutalne obrazowanie, mogłyby sugerować, że twórczość Sapkowskiego należałoby stawiać wśród tych wytworów kultury popularnej, w których dominującym środkiem artystycznego wyrazu jest pornografia śmierci — zjawisko szczegółowo opisane przez Geoffreya Gorera w eseju o tym samym tytule (Pornography of Death, 1955; pol. 1979). Pojęcie „pornografia śmierci” wprowadza on na zasadzie analogii do tradycyjnie rozumianej pornografii seksualnej. Jak zauważa:

Wydaje się, że jest wiele zbieżności między tworami fantazji, które wzbudzają nasze zainteresowanie tajemnicą płci, a tymi, które popychają je w kierunku tajemnicy śmierci. W obu rodzajach utworów uczucia z natury rzeczy towarzyszące tym aktom - miłość i żal — są prawie całkowicie pomijane ${ }^{52}$.

51 A. Gemra, Fantasy..., s. 181.

52 G. Gorer, Pornografia śmierci, przeł. I. Sieradzki, „Teksty” 1979, nr 3, s. 201. Gorer zauważa, że ekspansja pornografii śmierci w kulturze masowej XX wieku jest reakcją na opisane przez Philippe'a Arièsa zjawisko pruderii śmierci, czyli usuwanie śmierci naturalnej z przestrzeni publicznej, marginalizowanie jej i spuszczanie wstydliwej zasłony milczenia na sam fakt śmiertelności człowieka. To z kolei sprzyja eksponowaniu zgonów nagłych, drastycznych, widowiskowych. Jak twierdzi: „Pornografia jest niewątpliwie odwrotną stroną, cieniem pruderii, tak jak sprośność stano- 
Podkreślenie rangi emocji towarzyszących śmierci jest tu jednak kluczowe, jak można bowiem zauważyć, kres życia postaci nie jest w twórczości Sapkowskiego odseparowany od uczuć, które mogłyby towarzyszyć danej sytuacji w rzeczywistości pozatekstowej. W zależności od okoliczności może być to smutek, żal, ból czy strach, a efektowność obrazu nie przesłania warstwy emocjonalnej deskrypcji i nie staje się głównym źródłem satysfakcji odbiorcy.

Epatowanie okrucieństwem i szokowanie odbiorcy drastycznymi szczegółami nie jest u Sapkowskiego celem samym w sobie. Ulegająca przemocy istota ludzka bądź humanoidalna, poddana aktom gwałtu, nie jest tu bowiem jedynie „ciałem bez ducha, padliną, konstruktem przeznaczonym do otrzymywania i zadawania bólu" 53 , jak ma to miejsce w tekstach typu gore lub innych, w których pornografia śmierci jest przeważającym środkiem artystycznego wyrazu. Pierwsze skrzypce grają tu ból i cierpienie postaci — zarówno w warstwie cielesnej, jak i emocjonalnej — nie zaś estetyka makabry. Zastosowane przez Sapkowskiego zabiegi narracyjne uwydatniają uczucia bohatera i nie pozwalają się względem nich zdystansować. Krótkie, urywane zdania, które z pozoru wydawać by się mogły czysto sprawozdawcze i bezemocjonalne, często służą wytwarzaniu napięcia fabularnego poprzez zaburzanie ustalonego wcześniej rytmu i płynności narracji, dzięki czemu literackie reprezentacje śmierci w twórczości Sapkowskiego stają się bardzo przejmujące.

Śmierć w cyklu o wiedźminie bez wątpienia ma wymiar bardziej biologiczny niż duchowy, a najtrafniej określają ją skierowane do Ciri słowa Bonharta: „To jest śmierć. Tak się umiera. Popatrz, to są flaki. To krew. A to gówno. To człowiek ma w środku"54. Bezwzględne obnażenie brudu i fizjologii śmierci, wstydliwie skrywanych za zasłoną milczenia, natarczywie przypomina o ludzkim biologizmie. Jednocześnie zaprezentowanie naznaczonego przemocą ciała nie jako efektownego obiektu, ale jako jednostki powiązanej z innymi siecią rozmaitych emocjonalnych zależności, nie pozwala odrzucić głębszych reakcji emocjonalnych związanych z prezentowanymi scenami śmierci. Dzięki temu właśnie są one tak sugestywne.

\section{Bibliografia}

\section{Teksty źródłowe}

Bereś S., Sapkowski A., Historia i fantastyka, superNOWA, Warszawa 2005.

Chaciński B., Jestem ful-tajm rajterem [wywiad z A. Sapkowskim], „Machina” 2000, nr 4, https:// sapkowskipl.wordpress.com/2017/03/11/jestem-ful-tajm-rajterem/.

wi jedno z oblicz przyzwoitości” (ibidem, s. 197). Zob. także Ph. Ariès, Śmierć wyklęta, [w:] idem, Rozważania o historii śmierci, przeł. K. Marczewska, Warszawa 2007, s. 90-111; idem, Śmierć na opak, [w:] idem, Człowiek i śmierć, przeł. E. Bąkowska, Warszawa 2001, s. 557-597.

53 P. Sawicki, Odrażające, brudne, złe. 100 filmów gore, Wrocław 2011, s. 11.

54 A. Sapkowski, Wieża..., s. 72. 
Grabowski A.E., Kilka opowiadań mi się udało [wywiad z A. Sapkowskim], https://sapkowskipl. wordpress.com/2017/03/13/kilka-opowiadan-mi-sie-udalo/.

Piekara J., Dziewczyny rzeźnika, [w:] idem, Ja, inkwizytor. Wieże do nieba, Fabryka Słów, Lublin 2013.

Sapkowski A., Chrzest ognia, superNOWA, Warszawa 2001.

Sapkowski A., Czas pogardy, superNOWA, Warszawa 2001.

Sapkowski A., Krew elfów, superNOWA, Warszawa 2001.

Sapkowski A., Miecz przeznaczenia, superNOWA, Warszawa 2001.

Sapkowski A., Ostatnie życzenie, superNOWA, Warszawa 2001.

Sapkowski A., Pani Jeziora, superNOWA, Warszawa 2001.

Sapkowski A., Sezon burz, superNOWA, Warszawa 2013.

Sapkowski A., Wieża Jaskółki, superNOWA, Warszawa 2001.

Ziemkiewicz R., Rozpędzam się [wywiad z A. Sapkowskim], „Fantastyka” 1988, nr 8, https://sap kowskipl.wordpress.com/2017/03/11/rozpedzam-sie/.

\section{Opracowania}

Ariès Ph., Człowiek i śmierć, przeł. E. Bąkowska, Aletheia, Warszawa 2001.

Ariès Ph., Śmierć wyklęta, [w:] idem, Rozważania o historii śmierci, przeł. K. Marczewska, Oficyna Naukowa, Warszawa 2007.

Gemra A., Fantasy po polsku. Kilka uwag nad twórczościq Andrzeja Sapkowskiego, „Europa Orientalis" $2000, \mathrm{nr} 1$.

Gemra A., Literatura popularna. Literatura gatunków?, [w:] Retoryka i badania literackie. Rekonesans, red. J.Z. Lichański, Wydawnictwo Uniwersytetu Warszawskiego, Warszawa 1998.

Gorer G., Pornografia śmierci, przeł. I. Sieradzki, „Teksty” 1979, nr 3.

Guiomar M., Zasady estetyki śmierci, [w:] Wymiary śmierci, red. S. Rosiek, przeł. M. Ochab, T. Swoboda, M.L. Kalinowski, słowo/obraz terytoria, Gdańsk 2010.

Hollanek A., Szolgina K., Sondaż III. Wyniki!, „Fantastyka” 1987, nr 12.

Kaczor K., Bogactwo polskich światów fantasy. Od braku nadziei do eukatastophe, [w:] Anatomia wyobraźni, red. S.J. Konefał, Gdański Klub Fantastyki, Gdańsk 2014.

Kaczor K., Między obiegami. Powstanie polskiego pola literackiego fantasy 1982-1990, [w:] Przyjemność (z) czytania. Pamięci Profesora Tadeusza Żabskiego, red. A. Gemra, Pracownia Literatury i Kultury Popularnej oraz Nowych Mediów, Wrocław 2019.

Kaczor K., Z „,getta” do mainstreamu. Polskie pole literackie fantasy (1982-2012), Universitas, Kraków 2017.

Koziołek R., Popisy przemocy, [w:] idem, Ciała Sienkiewicza, Wydawnictwo Czarne, Wołowiec 2018.

Lichański J.Z., Literatura fantasy jako problem genologiczny (na przyktadzie twórczości C.S. Lewisa i J.R.R. Tolkiena), [w:] Genologia i konteksty, red. C.P. Dutka, M. Mikołajczyk, Wyższa Szkoła Pedagogiczna im. Tadeusza Kotarbińskiego, Zielona Góra 2000.

Morin E., Antropologia śmierci, [w:] Antropologia śmierci. Myśl francuska, red. S. Cichowicz, J.M. Godzimirski, przeł. S. Cichowicz, J.M. Godzimirski, wstęp S. Cichowicz, Wydawnictwo Naukowe PWN, Warszawa 1993.

Moroz A., Jak uwieść czytelnika? Jonathan Carroll i Andrzej Sapkowski wobec kulturowych koncepcji śmierci, Wydawnictwo Pisarze.pl, Warszawa 2014.

Nycz R., Tekstowy świat. Poststrukturalizm a wiedza o literaturze, Wydawnictwo Instytutu Badań Literackich PAN, Warszawa 1995.

Parowski M., Odkrywanie AS-a, Gram.pl, https://www.gram.pl/artykul/2007/10/24/odkrywanieas-a.shtml.

Literatura i Kultura Popularna 26, 2020

(C) for this edition by CNS 
Płoszaj J., Bezsilne ciała. Uwagi na temat przemocy przedstawionej w cyklu inkwizytorskim Jacka Piekary, [w:] Literatura i kultura popularna. Między tradycja a nowatorstwem, red. A. Gemra, Pracownia Literatury i Kultury Popularnej oraz Nowych Mediów, Wrocław 2016.

Płoszaj J., Między wzniosłościa a upodleniem. Obrazowanie oraz znaczenie śmierci w fantasy przygodowej i mitopoetyckiej, „Literatura i Kultura Popularna” 23, 2017.

Płoszaj J., Przerażajaco krwawe światy... Groza śmierci w polskiej literaturze fantasy na przykładzie twórczości Jacka Piekary i Andrzeja Ziemiańskiego, [w:] Światy grozy, red. K. Olkusz, Ośrodek Badawczy Facta Ficta, Kraków 2016, https://depot.ceon.pl/bitstream/handle/123456789/ $10227 / \%$ C5\%9Awiaty $\% 20$ grozy $\% 20-\% 20$ do\%20dystrybucji.pdf?sequence=1\&isAllowed=y.

Płoszaj J., Przygody pewnego wiedźmina. Konstrukcja i destrukcja schematów fabularnych w opowiadaniach Sapkowskiego, [w:] Wiedźmin — polski fenomen popkultury, red. R. Dudziński, J. Płoszaj, Stowarzyszenie Badaczy Popkultury i Edukacji Popkulturowej „Trickster”, Wrocław 2016, http://tricksterzy.pl/download/wiedzmin-polski-fenomen-popkultury/.

Płoszaj J., ,,W walce o sluszna sprawę nie ma etyki”. Funkcje i sposoby przedstawiania przemocy w trylogii husyckiej Andrzeja Sapkowskiego, [w:] Stowiańszczyzna dawniej i dziś — język, literatura, kultura. Monografia ze studiów slawistycznych III, red. A. Kołodziej, współp. T. Piasecki, Nakladatelství Pavel Mervart, Červený Kostelec 2017.

Rogoż M., Pomiędzy konwencją a mimesis — różne wymiary świata przedstawionego w opowiadaniach Andrzeja Sapkowskiego Ostatnie życzenie $i$ Miecz przeznaczenia, [w:] Fantastyczność i cudowność. Wokót źródel fantasy, red. B. Trocha, T. Ratajczak, Wydawnictwo Uniwersytetu Zielonogórskiego, Zielona Góra 2009.

Roszczynialska M., Sztuka fantasy Andrzeja Sapkowskiego. Problemy poetyki, Wydawnictwo Naukowe Uniwersytetu Pedagogicznego, Kraków 2009.

Sapkowski A., Piróg, albo Nie ma złota w Szarych Górach, „Nowa Fantastyka” 1993, nr 5.

Sawicki P., Odrażające, brudne, złe. 100 filmów gore, Wydawnictwo Yohei, Wrocław 2011.

Sondaż VI - opowiadania polskie, „Nowa Fantastyka” 1990, nr 9.

Szolgina K., Sondaż V—wyniki, „Fantastyka” 1989, nr 12.

Thomas L.V., Doświadczanie śmierci: jego granice i rzeczywistość, [w:] Antropologia śmierci. Myśl francuska, red. S. Cichowicz, J.M. Godzimski, przeł. S. Cichowicz, J.M. Godzimski, wstęp S. Cichowicz, Wydawnictwo Naukowe PWN, Warszawa 1993.

Tkacz M., Baśnie zbyt prawdziwe. Trzydzieści lat fantasy w Polsce, Gdański Klub Fantastyki, Gdańsk 2012.

Wałaszewski Z., Wiedźmin: pierwszy polski supersystem rozrywkowy, [w:] Obraz literatury w komunikacji społecznej po roku '89, red. A. Werner, T. Żukowski, Instytut Badań Literackich, Warszawa 2013.

Żabski T., Literatura popularna, [hasło w:] Słownik literatury popularnej, red. T. Żabski, Wydawnictwo Uniwersytetu Wrocławskiego, Wrocław 2006.

\section{Blood and dirt: Aesthetics and poetics of descriptions of death in Andrzej Sapkowski's The Witcher literary series}

Summary

Andrzej Sapkowski's The Witcher series is the first Polish fantasy series that has gained so much popularity. When Sapkowski published his first story - The Witcher - in 1986, fantasy literature wasn't well-known in Poland. In fact Polish readers, who were interested in fantasy, would 
mainly know John R.R. Tolkien's novels like The Hobbit, Or Thete and Back Again, The Lord of the Rings or Silmarillion, all belonging to mythopoeic fantasy. Sapkowski's story was vastly different from them, because the Polish author referred to sword and sorcery literature, which at that time was little-known in Poland. He created an interesting protagonist and a dark, vicious world, full of violence and graphic descriptions of death.

It appears that one of the main factors having an influence on the huge popularity of the series, may be the attempt to shock the reader by using a unique construction of the presented world, which contains a lot of graphic violent imagery. This article presents those methods of description of death and violence in The Witcher series to present why they are so interesting to the readers and what makes them stand out from the rest of similar descriptions in Polish fantasy literature.

The analysis is divided into several parts. The first part presents the influence of Sapkowski's debut story on Polish fantasy literature. The second part contains the analysis of the dynamics of descriptions of death. The third and the fourth focus on showing the individualisation of death in The Witcher series and on detail exposure. The next part presents the narrative treatments used by Sapkowski to increase the impact of the literary images of death, for example changes of a narrative perspective. The last part of the article presents naturalistic elements of the descriptions and explains what functions they perform in the text. 